\title{
N-Terminal Extension of Sweet Peptides in Relation to the Structural Features of Peptide Sweeteners
}

\author{
Yasuo Ariyoshi, Yasunobu Hasegawa, Masafumi Ota \\ and Noriki Nio \\ Central Research Laboratories, Ajinomoto Co., Inc., \\ 1-1 Suzuki-cho, Kawasaki-ku, Kawasaki 210, Japan \\ Received November 13, 1989
}

\begin{abstract}
Sweet aspartyl di- and tripeptide esters were extended toward the $\mathrm{N}$-terminus in relation to the structural features of sweet peptides. The sweet peptides were designed on the basis of the receptor site model. It was found that an extension of the sweet aspartyl dipeptide esters by adding a small D-amino acid residue mostly gave sweet compounds (e.g., D-Ala-L-Asp-D-Ala-OMe), although this significantly decreased their sweetness potencies. Further extension at the $\mathbf{N}$-terminus of the extended sweet tripeptide esters to yield the tetrapeptide esters resulted in a loss of the sweet taste. The $\mathrm{N}$-terminal extension of sweet aspartyl tripeptide esters resulted in faintly sweet or nonsweet tetrapeptide esters. Interestingly, an analogous extension at the $\mathrm{N}$-terminus of the sweet aminomalonyl dipeptide esters gave bitter compounds (e.g., D-Ala-DL-Ama-L-Phe-OMe). These results indicate that the receptor has a small space that can accomodate an additional small $D$-amino acid residue at the site facing the $\mathrm{N}$ terminus of sweet aspartyl dipeptide esters.
\end{abstract}

Since the discovery of a sweet taste in LAsp-L-Phe-OMe, ${ }^{1)}$ a large number of aspartyl $\mathrm{di}-_{-}{ }^{2-6)}$ tri-,${ }^{7,8)}$ tetra- ${ }^{9)}$ and pentapeptide ${ }^{10)}$ analogues have been synthesized in an attempt to elucidate the structure-taste relationship and to draw the mode of interaction between the sweet peptides and their receptor. The effort, however, has mostly been made on modifying the L-Phe moiety of L-Asp-L-Phe-OMe. As a result, the hydrophobic and steric properties of this moiety have been well established.

On the other hand, only a few modifications of the L-Asp moiety have been reported in the literature. It has been demonstrated that the $L-$ Asp moiety of L-Asp-L-Phe-OMe is restricted to L-Asp or aminomalonic acid (Ama). The LAsp moiety has been replaced by $A m a^{11,12)}$ or $\mathrm{CF}_{3} \mathrm{CO}-\mathrm{L}-\mathrm{Asp},{ }^{13)}$ retaining the substantial sweetness potency.

Possible sweet conformations of the sweet peptides have also been analyzed by means of NMR spectroscopy, ${ }^{6,14,15)}$ X-ray crystallography ${ }^{5,16,17)}$ and quantitative structure-activity relationships. ${ }^{18,19)}$

On the basis of these synthetic and physi- cochemical studies, several types of receptor site model have been reported. ${ }^{4,10,14,18-21)}$ Our series of synthetic studies have led us to draw the mode of interaction between the sweet peptides and their receptor. ${ }^{10)}$ In all the proposed receptor models, the mode of interaction between the sweet peptides and their receptor has been discussed on the basis of studies on the structure-taste relationship of sweet aspartyl dipeptide analogues, and the free $\alpha$-amino and $\beta$-carboxyl groups of the $\mathrm{L}-$ Asp residue have been considered to trigger the sweetness by forming hydrogen bonding with the receptor. The amino and carboxyl groups serve as a proton donor $(\mathrm{AH})$ and a proton acceptor (B), respectively, in hydrogen bonding. ${ }^{22)}$ In these models, if there is a space left at the site facing the N-terminus of the sweet peptides, it can be considered that certain peptides extended at the $\alpha$-amino or $\beta$ carboxyl group of the L-Asp residue will probably taste sweet when they have a suitable size and configuration. No such attempt on this has been made so far. This paper deals with the design of novel sweet peptides 
based on a view of the sweet receptor mod$\mathrm{el}^{10)}$ and their synthesis. ${ }^{23)}$

\section{Materials and Methods}

Abbreviations follow the recommendations of the IUPAC-IUB Commission on Biochemical Nomenclature in Eur. J. Biochem., 138, 9 (1984). Other abbreviations used: AA, amino acid; -OFn, fenchyloxy; HPLC, highperformance liquid chromatography; TLC, thin-layer chromatography; $\mathrm{Et}_{3} \mathrm{~N}$, triethylamine; TFA, trifluoroacetic acid; TosOH, p-toluenesulfonic acid; HOSu, $N$ hydroxysuccinimide; DCC, dicyclohexylcarbodiimide.

The amino acid esters and protected amino acids used in this study were obtained from Kokusan Chemical Works Ltd. and Peptide Institute Inc., respectively. Diethyl aminomalonate hydrochloride and $(+)$ - $\alpha$-fenchyl alcohol were purchased from Aldrich Chemical Co., Inc. The amino acid propyl esters and D-amino acid esters were synthesized in our laboratory, all the peptides, except $\mathrm{Z}-\mathrm{L}-$ $A \operatorname{sp}(\mathrm{OH})$-L-Phe-OMe and Z-D(or L)-Ala-DL-Ama(OBzl)$\mathrm{OH}$, being synthesized by the conventional active ester method using the $N$-hydroxysuccinimide ester of protected amino acids. The Boc group was employed for protecting the amino group of the intermediate peptides, and was removed with $\mathrm{HCl} /$ dioxane. The $\beta$-carboxyl group of the Asp residue was protected with the benzyl group, and the $Z$ group was used for protecting the penultimate intermediates. The benzyl and $Z$ groups were removed by hydrogenation over $\mathrm{Pd} / \mathrm{C}$ to give the desired peptides. $\mathrm{Z}-\mathrm{L}$ Asp $(O H)$-L-Phe-OMe was synthesized by the enzymatic method. $^{24)}$ Z-D(or L)-Ala-DL-Ama(OBzl)-AA-OMe was synthesized by condensing H-AA-OMe with Z-D(or L)Ala-DL-Ama(OBzl)-OH, which was obtained by treating Z-D(or L)-Ala-DL-Ama(OEt)-OEt with $\mathrm{NaOH}$ (or $\mathrm{KOH}$ ) in benzyl atcohol. In the synthesis of D-Ala-L-Glu-L-PheOMe, an attempted condensation of $\mathrm{H}-\mathrm{L}-\mathrm{Glu}(\mathrm{OBzl})-\mathrm{L}-$ $\mathrm{Phe}-\mathrm{OMe} \cdot \mathrm{HCl}$ with $\mathrm{Z}$-D-Ala-OSu was unsuccessful, because the dipeptide ester hydrochloride readily changed to the corresponding pyroglutamyl dipeptide ester $(<$ GluPhe-OMe) when it was neutralized with $\mathrm{Et}_{3} \mathrm{~N}$. Thus, LGlu-L-Phe-OMe ${ }^{1)}$ was condensed with $\mathrm{Z}$-D-Ala-OSu to give $\mathrm{Z}-\mathrm{D}-\mathrm{Ala}$-L-Glu(OH)-L-Phe-OMe $(28 \%$ yield), which was then hydrogenated over $\mathrm{Pd} / \mathrm{C}$ to give D-Ala-L-Glu-LPhe-OMe ( $80 \%$ yield). The following dipeptide esters were newly synthesized for this study: L-Asp-D-Val-OMe (6), LAsp-L-Pro-OMe (13), L-Asp-D-Pro-OMe (14), L-Asp-DAla-OFn (17), DL-Ama-D-Ala-OMe (27), L-Glu-Gly-OMe and L-Glu-D-Ala-OMe.

All melting points (mp) were taken on a Yamato Model MP-21 capillary melting point apparatus and are uncorrected. Analytical HPLC was carried out on a Waters M600 instrument under linear gradient conditions $\left(C_{18}\right.$ reversed-phase column, Inertsil ODS, Gasukuro Kogyo, $4.6 \times 250 \mathrm{~mm}$; solvent $\mathrm{A}, 0.05 \%$ aqueous TFA; solvent $\mathrm{B}$, acetonitrile containing $0.05 \% \mathrm{TFA}$; flow rate, $1.0 \mathrm{ml} / \mathrm{min}$;
UV detection at $210 \mathrm{~nm}$ ). TLC was performed on precoated silica gel 60 F-254 plates (E. Merck) using solvent system $A$, chloroform: methanol:acetic acid: : water $=$ $32: 15: 1: 3(\mathrm{v} / \mathrm{v})$ or solvent system B, 1-butanol:acetic acid : water $=4: 1: 1(\mathrm{v} / \mathrm{v})$, and the spots were detected with ninhydrin. All compounds were essentially homogeneous by TLC.

Peptide synthesis. Typical runs (compounds 1, 25 and 31 in Table I) were as follows:

$B o c-\mathrm{L}-A s p(O B z l)-\mathrm{D}-A l a-O M e$ (1a). Boc-L-Asp(OBzl)$\mathrm{OSu}^{25)}(5.40 \mathrm{~g}, 12.8 \mathrm{mmol})$ was added to an ice-cooled, stirred solution of $\mathrm{H}-\mathrm{D}-\mathrm{Ala}-\mathrm{OMe} \cdot \mathrm{HCl}(2.00 \mathrm{~g}, 14.3 \mathrm{mmol})$ and $\mathrm{Et}_{3} \mathrm{~N}(2.0 \mathrm{ml}, 14.3 \mathrm{mmol})$ in chloroform $(50 \mathrm{ml})$. The resulting mixture was stirred in an ice-bath for $1 \mathrm{hr}$, and then stirred at room temperature for $3 \mathrm{hr}$ and kept standing overnight. The mixture was washed with water, a $10 \%$ citric acid solution, a $5 \% \mathrm{NaHCO}_{3}$ solution and water, and then concentrated under reduced pressure. The residue thus obtained was crystallized from ethyl acetatehexane to give 1a as crystals. Recrystallization was carried out from the same solvent to give 1a as needles. Yield, $4.93 \mathrm{~g}(93.9 \%) ; \mathrm{mp} 53.0-53.5^{\circ} \mathrm{C}$. Found: C, 59.10; H, 7.10; $\mathrm{N}, 6.88$. Calcd. for $\mathrm{C}_{20} \mathrm{H}_{28} \mathrm{O}_{7} \mathrm{~N}_{2}: \mathrm{C}, 58.81: \mathrm{H}, 6.91 ; \mathrm{N}$, $6.86 \%$

Z-D-Ala-L-Asp(OBzl)-D-Ala-OMe (1b). Boc-L-Asp(OBzl)-D-Ala-OMe (1a, $3.00 \mathrm{~g}, 7.3 \mathrm{mmol})$ was dissolved in $18.4 \mathrm{ml}$ of $4 \mathrm{~N} \mathrm{HCl}$ in dioxane and kept at room temperature for $1 \mathrm{hr}$, after which hexane $(100 \mathrm{ml})$ was added to the reaction mixture to precipitate the desired product. The solvent was removed by decantation. The precipitate thus obtained was dissolved in chloroform $(30 \mathrm{ml})$ and neutralized with $\mathrm{Et}_{3} \mathrm{~N}$ in an ice-bath. Z-D-Ala$\mathrm{OSu}^{26)}(2.12 \mathrm{~g}, 6.6 \mathrm{mmol})$ was added to this ice-cooled solution with stirring. The mixture was stirred while cooling for $1 \mathrm{hr}$, and then stirred at room temperature for $3 \mathrm{hr}$ and kept standing overnight. The reaction mixture was washed successively with water, $1 \mathrm{~N} \mathrm{HCl}$, a $5 \%$ $\mathrm{NaHCO}_{3}$ solution and water, and then concentrated under reduced pressure. The residue was crystallized from ethyl acetate-hexane to give $\mathbf{1 b}$ as a powder. Recrystallization was carried out from the same solvent to give pure $\mathbf{1 b}$ as a powder. Yield, $2.11 \mathrm{~g}(62.1 \%)$; mp $135.0-136.5^{\circ} \mathrm{C}$. Found: $\mathrm{C}, 60.92, \mathrm{H}, 6.00 ; \mathrm{N}, 8.32$. Caled. for $\mathrm{C}_{26} \mathrm{H}_{31} \mathrm{O}_{8} \mathrm{~N}_{3}: \mathrm{C}$, $60.81 ; \mathrm{H}, 6.08 ; \mathrm{N}, 8.18 \%$.

D-Ala-L-Asp-D-Ala-OMe (1). Z-D-Ala-L-Asp(OBzl)-DAla-OMe (1b, $2.43 \mathrm{~g}, 4.7 \mathrm{mmol})$ was dissolved in a mixture of acetic acid $(40 \mathrm{ml})$ and water $(10 \mathrm{ml})$, and hydrogenated in the presence of $5 \% \mathrm{Pd}$ on charcoal $(0.5 \mathrm{~g})$ with stirring at atmospheric pressure and room temperature for $5 \mathrm{hr}$. The reaction mixture was filtered, and the filtrate was concentrated under reduced pressure to dryness. The residue was dissolved in water, and the solvent was evaporated under reduced pressure to remove any remaining acetic acid. The procedure was repeated three times, the residue then being recrystallized from water-acetone to give 1 as a powder. Recrystallization from the same sol- 
vent gave pure 1 as a powder. Yield, $0.61 \mathrm{~g}(44.5 \%)$; mp $239-240^{\circ} \mathrm{C}$ (decomp.). TLC, $R f=0.19$ (solvent system A). Found: C, 45.51; H, 6.82; N, 14.48. Calcd. for $\mathrm{C}_{11} \mathrm{H}_{19} \mathrm{O}_{6} \mathrm{~N}_{3}: \mathrm{C}, 45.67 ; \mathrm{H}, 6.62 ; \mathrm{N}, 14.53 \%$.

Z-D-Ala-DL-Ama(OEt)-OEt (25a). Z-D-Ala-OSu (4.80 g, $15 \mathrm{mmol}$ ) was added to an ice-cooled, stirred solution of $\mathrm{H}$-DL-Ama(OEt)-OEt $\cdot \mathrm{HCl}(3.81 \mathrm{~g}, 18 \mathrm{mmol})$ and $\mathrm{Et}_{3} \mathrm{~N}$ $(1.82 \mathrm{~g}, 18 \mathrm{mmol})$ in chloroform $(60 \mathrm{ml})$. The mixture was stirred at room temperature for $2 \mathrm{hr}$ and then kept standing overnight. The reaction mixture was successively washed with water, $1 \mathrm{~N} \mathrm{HCl}$, a $5 \% \mathrm{NaHCO}_{3}$ solution and water, and then concentrated under reduced pressure. The residue was crystallized from ethyl acetate-hexane to give 25a as needles. Recrystallization from the same solvent gave pure 25a as needles. Yield, $5.07 \mathrm{~g}(88.9 \%)$; mp $122-123^{\circ} \mathrm{C}$. Found: C, 56.78; H, 6.21; N, 7.34. Calcd. for $\mathrm{C}_{18} \mathrm{H}_{24} \mathrm{O}_{7} \mathrm{~N}_{2}: \mathrm{C}, 56.83 ; \mathrm{H}, 6.36 ; \mathrm{N}, 7.37 \%$

$Z$-D-Ala-DL-Ama $(O B z l)-O H$ (25b). A warm solution of Z-D-Ala-DL-Ama(OEt)-OEt (25a, $4.57 \mathrm{~g}, 12 \mathrm{mmol})$ in benzyl alcohol $(12 \mathrm{ml})$ was added to a warm solution containing $\mathrm{NaOH}(0.48 \mathrm{~g})$ in benzyl alcohol $(20 \mathrm{ml})$. The mixture was stirred at room temperature for $4.5 \mathrm{hr}$. Ether $(50 \mathrm{ml})$ and hexane $(300 \mathrm{ml})$ were successively added to the mixture to precipitate the desired product. The solvent was removed by decantation, and the syrupy precipitate was triturated in water to give crystals, which were then triturated in $1 \mathrm{~N} \mathrm{HCl}(12 \mathrm{ml})$ and filtered. Yield, $2.45 \mathrm{~g}(48.1 \%)$. Recrystallization from ethyl acetate-hexane gave pure $25 \mathbf{b}$ as needles, $m p 89^{\circ} \mathrm{C}$ (softened at $83^{\circ} \mathrm{C}$ ). Found: $\mathrm{C}, 59.66 ; \mathrm{H}, 5.43 ; \mathrm{N}, 6.72$. Calcd. for $\mathrm{C}_{21} \mathrm{H}_{22} \mathrm{O}_{7} \mathrm{~N}_{2} \cdot 1 / 2 \mathrm{H}_{2} \mathrm{O}: \mathrm{C}, 59.57 ; \mathrm{H}, 5.48 ; \mathrm{N}, 6.62 \%$. In the synthesis of its isomer, Z-L-Ala-DL-Ama(OBzl)-OH, $\mathrm{KOH}$ in benzyl alcohol was used instead of $\mathrm{NaOH}$, because $\mathrm{KOH}$ could be dissolved in the benzyl alcohol without warming.

Z-D-Ala-DL- $A m a(O B z l)$-L-Phe-OMe (25c). Z-D-Ala$\mathrm{DL}-\mathrm{Ama}(\mathrm{OBz})-\mathrm{OH}(\mathbf{2 5 b}, 2.22 \mathrm{~g}, 5.2 \mathrm{mmol})$ and $\mathrm{DCC}$ $(1.24 \mathrm{~g}, 6 \mathrm{mmol})$ were added to an ice-cooled, stirred solution of $\mathrm{H}-\mathrm{L}-\mathrm{Phe}-\mathrm{OMe} \cdot \mathrm{HCl}(1.55 \mathrm{~g}, 7.2 \mathrm{mmol}), \mathrm{Et}_{3} \mathrm{~N}$ $(0.73 \mathrm{~g}, 7.2 \mathrm{mmol})$ and HOSu $(0.83 \mathrm{~g}, 7.2 \mathrm{mmol})$ in chloroform $(50 \mathrm{ml})$. The mixture was stirred at room temperature for $2 \mathrm{hr}$ and then kept standing overnight. A few drops of acetic acid were added to the reaction mixture with stirring. After $10 \mathrm{~min}$, the mixture was successively washed with water, $1 \mathrm{~N} \mathrm{HCl}$, a $5 \% \mathrm{NaHCO}_{3}$ solution and water, and then concentrated under reduced pressure. The residue was crystallized from ethyl acetate-hexane to give $25 \mathrm{c}$ as a powder. Yield, $1.75 \mathrm{~g}(58.0 \%)$. Recrystallization from the same solvent gave $\mathbf{2 5 c}$ as needles; mp 162 $164^{\circ} \mathrm{C}$. Further recrystallization from ethyl acetate raised the mp to $164-166^{\circ} \mathrm{C}$. Found: $\mathrm{C}, 64.76 ; \mathrm{H}, 5.74 ; \mathrm{N}, 7.52$. Calcd. for $\mathrm{C}_{31} \mathrm{H}_{33} \mathrm{O}_{8} \mathrm{~N}_{3}$ : C, 64.68; $\mathrm{H}, 5.78 ; \mathrm{N}, 7.30 \%$.

D-Ala-DL-Ama-L-Phe-OMe (25). Z-D-Ala-DL-Ama(OBzl)-L-Phe-OMe $(\mathbf{2 5 c}, 1.20 \mathrm{~g})$ was dissolved in a mixture of acetic acid $(30 \mathrm{ml})$ and water $(10 \mathrm{ml})$, and hydrogenated in the presence of $5 \% \mathrm{Pd}$ on charcoal $(0.48 \mathrm{~g})$ at atmospheric pressure and room temperature for $5 \mathrm{hr}$.
After filtering, the filtrate was concentrated under reduced pressure to dryness. The residue was dissolved in water, and the solvent was evaporated under reduced pressure to remove the remaining acetic acid. This procedure was repeated three times, and the residue was crystallized from water-acetone to give 25 as a powder. Yield, $0.49 \mathrm{~g}(64.5 \%)$. Recrystallization from the same solvent gave $\mathbf{2 5}$ as fluffy crystals; $\mathrm{mp} 150^{\circ} \mathrm{C}$ (decomp.). HPLC analysis revealed that the compound (25) was a $1: 1$ mixture of the D-D-L and D-L-L isomers. The sample was eluted with a linear gradient of $10 \% \mathrm{~B}$ to $50 \% \mathrm{~B}$ in $20 \mathrm{~min}$. TLC, $R f=0.37$ (solvent system B). Found: C, 52.57; $\mathrm{H}$, 5.96; N, 11.49. Caled. for $\mathrm{C}_{16} \mathrm{H}_{21} \mathrm{O}_{6} \mathrm{~N}_{3} \cdot 3 / 4 \mathrm{H}_{2} \mathrm{O}: \mathrm{C}, 52.67$; $\mathrm{H}, 6.22 ; \mathrm{N}, 11.52 \%$.

Z-L-Asp(-L-Ala-OBzl)-L-Phe-OMe (31a). Z-L-Asp(OH)$\mathrm{L}-\mathrm{Phe}-\mathrm{OMe} \cdot \mathrm{H}-\mathrm{L}-\mathrm{Phe}-\mathrm{OMe}(8.97 \mathrm{~g})^{24)}$ was suspended in $40 \mathrm{ml}$ of $1 \mathrm{~N} \mathrm{HCl}$ and stirred at room temperature for $45 \mathrm{~min}$. The insoluble $\mathrm{Z}$-L-Asp $(\mathrm{OH})$-L-Phe-OMe was filtered and washed with water. Recrystallization from ethyl acetate-hexane gave $\mathrm{Z}$-L-Asp $(\mathrm{OH})$-L-Phe-OMe $\cdot 1 / 2 \mathrm{H}_{2} \mathrm{O}$ $(5.03 \mathrm{~g})$ as needles. Z-L-Asp $(\mathrm{OH})$-L-Phe-OMe $\cdot 1 / 2 \mathrm{H}_{2} \mathrm{O}$ $(2.19 \mathrm{~g}, 5 \mathrm{mmol})$, DCC $(1.03 \mathrm{~g}, 5 \mathrm{mmol})$ and HOSu $(0.69 \mathrm{~g}$, $6 \mathrm{mmol}$ ) were added to an ice-cooled, stirred solution of $\mathrm{H}-\mathrm{L}-\mathrm{Ala}-\mathrm{OBzl} \cdot \mathrm{TosOH}(2.11 \mathrm{~g}, 6 \mathrm{mmol})$ and $\mathrm{Et}_{3} \mathrm{~N}(0.61 \mathrm{~g}$, $6 \mathrm{mmol}$ ) in $40 \mathrm{ml}$ of chloroform. The mixture was stirred at room temperature for $3 \mathrm{hr}$ and then kept standing overnight. A few drops of acetic acid were added to the reaction mixture with stirring. After $15 \mathrm{~min}$, the mixture was successively washed with water, $1 \mathrm{~N} \mathrm{HCl}$ and water, and then concentrated under reduced pressure. The residue was recrystallized from ethyl acetate and gave $\mathbf{3 1 a}$ as needles. Recrystallized from ethyl acetate gave pure $31 \mathrm{a}$ as needles. Yield, $1.77 \mathrm{~g}(60.0 \%) ; \mathrm{mp} 160-161^{\circ} \mathrm{C}$ (decomp.). Found: C, 65.15; H, 6.03; N, 7.17. Calcd. for $\mathrm{C}_{32} \mathrm{H}_{35} \mathrm{O}_{8} \mathrm{~N}_{3}: \mathrm{C}, 65.18 ; \mathrm{H}, 5.98 ; \mathrm{N}, 7.13 \%$.

$\mathrm{L}-A s p(-\mathrm{L}-A l a-O H)$-L-Phe-OMe (31). Z-L-Asp(-L-AlaOBzl)-L-Phe-OMe $(31 \mathrm{a}, 1.60 \mathrm{~g})$ was dissolved in a mixture of acetic acid $(30 \mathrm{ml})$ and water $(10 \mathrm{ml})$, and hydrogenated in the presence of $5 \% \mathrm{Pd}$ on charcoal $(0.4 \mathrm{~g})$ with stirring at atmospheric pressure and room temperature for $4 \mathrm{hr}$. The reaction mixture was filtered, and the filtrate was concentrated under reduced pressure to dryness. The residue was dissolved in water, and the solvent was evaporated under reduced pressure to remove the remaining acetic acid. This procedure was repeated four times, and recrystallization was carried out from water. Yeild, $0.68 \mathrm{~g}$ $\left(68.7 \%\right.$ ); mp $200^{\circ} \mathrm{C}$ (decomp.). TLC, $R f=0.50$ (solvent system B). Found: C, 55.95; H, 6.16; N, 11.48. Calcd. for $\mathrm{C}_{17} \mathrm{H}_{23} \mathrm{O}_{6} \mathrm{~N}_{3}: \mathrm{C}, 55.88 ; \mathrm{H}, 6.35 ; \mathrm{N}, 11.50 \%$.

Sweetness evaluation. The sweetness potency of the synthetic peptides was organoleptically determined by an evaluation panel of five untrained people. The evaluation was carried out at concentrations near the threshold because the quantity of the peptides obtained here was insufficient for an evaluation at practical sucrose levels $(5-10 \%)$. The sweetness evaluation was carried out by 
matching the concentration of each peptide with a $0.6 \%$ sucrose solution. The sweetness potency of the weakly sweet compounds was determined by one to three people because of the limited quantities available. An accurate evaluation of weakly sweet compounds needs a large sample quantity. The quantity of each weakly sweet peptide obtained here was insufficient for the full panel to evaluate, and no attempt was made to quantitate the sweetness potency.

\section{Results and Discussion}

In Fig. 1, in order for the peptide to be sweet, small alkyl groups $\mathrm{R}^{2}$ and $\mathrm{R}^{4}$ had to be placed below the projection plane when the backbone chain of the peptides is laid on the plane of the paper. ${ }^{7)}$ This fact may suggest that a hydrophobic area, which involves hydrophobic binding interactions that amplify the sweetness potency, resides below the plane. Therefore, in the structural modifications of the sweet peptides (Table I), it was assumed that small alkyl groups also had to be placed below the projection plane for the compounds to exhibit a sweet taste.

(i) Modifications at the free $\alpha$-amino group of sweet aspartyl dipeptides (compounds 1-20 in Table I).

A D-amino acid residue was introduced for the first amino acid in order to meet the assumed sweet structure, in which a small alkyl group $\left(\mathrm{R}^{2}\right.$ of the first projection formula in Table I) was placed below the plane so as to interact with the above-mentioned hydrophobic area of the receptor. As expected, coupling a sweet dipeptide, L-Asp-D-Ala$\mathrm{OMe}^{27)}$ with a D-Ala residue gave 1 , retaining half of the original sweetness potency. In order to confirm the importance of the orientation of the small alkyl group $\left(\mathrm{R}^{2}\right)$, the L-antipode ( $\mathrm{L}$ Ala) was coupled with L-Asp-D-Ala-OMe to give 2 , which was faintly sweet when tasted as crystals, but was tasteless when tasted as its $1 \%$ solution. This shows that the orientation of a

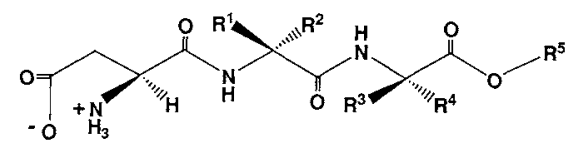

Fig. 1. L- $\alpha$-Aspartyl Tripeptide Esters. hydrophobic group at $\mathrm{R}^{2}$ was critical. Replacement of the methyl group at $R^{2}$ of 1 by an isopropyl group gave $\mathbf{3}$, which was faintly sweet $(0.3 \times$ sucrose $)$. Analogously, sweet dipeptides $\quad$ L-Asp-D-Ala-OPr, ${ }^{27)} \quad$ L-Asp-D-ValOMe (6, newly synthesized) and L-Asp-L-Phe$\mathrm{OMe}^{11}$ were successfully extended at the $\mathrm{N}$-terminus to give sweet tripeptides 4, 5, 7 and 11, although their sweetness potencies were significantly decreased.

Extension at the N-terminus of L-Asp-LPhe-OMe by the addition of a D-Ala residue gave a sweet compound (11), but an extended compound (12) by adding the L-antipode ( $\mathrm{L}^{-}$ Ala) had a weakly sweet taste along with a bitter taste. In conjunction with the result obtained from the examination of compounds 1 and 2, this result supports the idea that a small alkyl group $\left(\mathrm{R}^{2}\right)$ should be placed below the projection plane to elicit a sweet taste.

Compound 5 with a D-Pro residue at the Nterminus was moderately sweet. Analogously, D-prolyl tripeptides 9 and $\mathbf{1 0}$ were expected to exhibit a sweet taste, but contrary to our expectations, they were tasteless. It seems that, by increasing the size of the peptide, it became difficult to fit into the small receptor site. As was seen in the case of compound $\mathbf{3}$, the introduction of an isopropyl group at $\mathrm{R}^{2}$ significantly decreased the sweetness potency. Therefore, an extension at the $\mathrm{N}$-terminus of L-Asp-D-Val-OMe by the addition of a D-Val residue was predicted to give a nonsweet compound. As expected, the resulting compound 8 was tasteless.

Although L-Asp-L-Pro-OMe (13) and L-AspD-Pro-OMe (14) were devoid of sweetness, their extended analogues were synthesized to learn the taste properties of such prolinecontaining peptides (15 and 16); compounds. 15 and 16 were both bitter. L-Aspartyl-Dalanine $(+)-\alpha$-fenchyl ester (17) was 40 times sweeter than sucrose, but elongation at the $\mathrm{N}$ terminus of 17 by adding a D-Ala residue to yield $\mathbf{1 8}$ resulted in a complete loss of sweetness.

With the exceptions of some compounds, most of the tripeptides derived from sweet 
Table I. Taste of the Synthetic Peptides

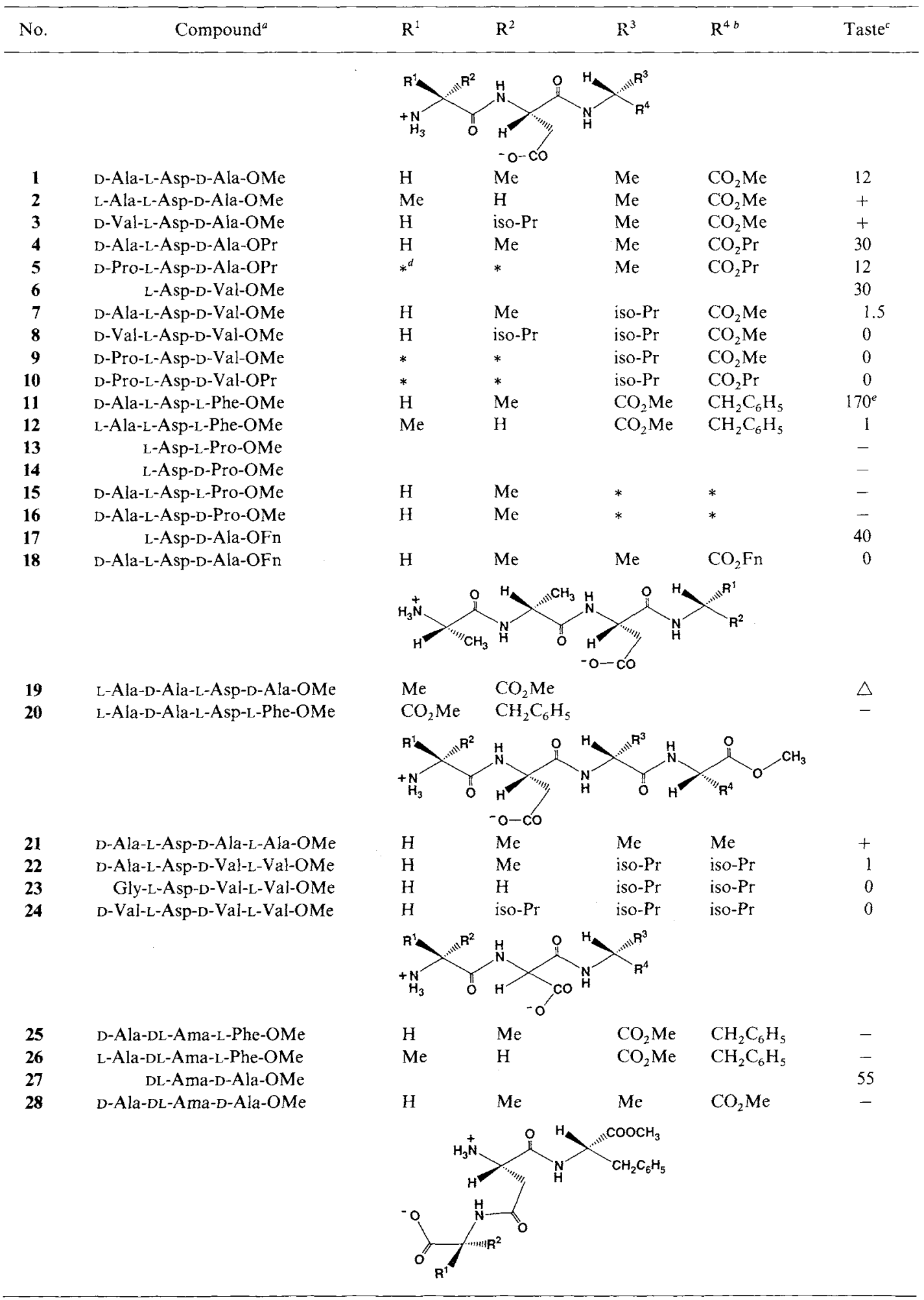


Table 1. (continued)

\begin{tabular}{|c|c|c|c|c|c|c|}
\hline No. & Compound $^{a}$ & $\mathrm{R}^{1}$ & $\mathrm{R}^{2}$ & $\mathbf{R}^{3}$ & $\mathrm{R}^{4 b}$ & Taste $^{c}$ \\
\hline 29 & L-Asp(-Gly-OH)-L-Phe-OMe & $\mathrm{H}$ & $\mathrm{H}$ & & & 0 \\
\hline 30 & L-Asp(-D-Ala-OH)-L-Phe-OMe & $\mathrm{H}$ & $\mathrm{Me}$ & & & 0 \\
\hline 31 & L-Asp(-L-Ala-OH)-L-Phe-OMe & $\mathrm{Me}$ & $\mathrm{H}$ & & & 0 \\
\hline
\end{tabular}

a Abbreviations used: -OPr, propyloxy; -OFn, (+)- $\alpha$-fenchyloxy; Ama, aminomalonic acid.

$b$ Abbreviations used: Me, methyl; iso- $\mathrm{Pr}$, isopropyl; $\mathrm{Fn},(+)$ - $\alpha$-fenchyl.

Numbers represent the sweetness potency of the compound as a multiple of sucrose; $t$, faintly sweet $(<1) ; 0$, tasteless; - , bitter; $\triangle$, astringent.

d The projection formula is not applicable to compounds $5,9,10,15$ and 16.

e Aspartame (L-Asp-L-Phe-OMe) is 215-133 and 400 times sweeter than sucrose at practical sucrose levels (4.3$10 \%$ ) and the threshold level, respectively; see ref. 30 .

aspartyl dipeptides were found to be sweet. Therefore, it can be concluded that the receptor has a space left at the site facing the $\mathrm{N}$ terminus of sweet aspartyl dipeptides. This space can accomodate an additional small $\mathrm{D}$ amino acid. It can be assumed that the newly introduced $\alpha$-amino and the original $\beta$-carboxyl groups serve as a proton donor $(\mathrm{AH})$ and a proton acceptor (B) in the AH-B system, respectively.

Next, the sweet tripeptides already obtained, D-Ala-L-Asp-D-Aal-OMe (1) and D-Ala-LAsp-L-Phe-OMe (11), were further extended at the $\mathrm{N}$-terminus by adding an L-Ala residue to give compounds 19 and 20, which were astringent and bitter, respectively. In these compounds, all the small alkyl groups were placed below the projection plane so as to meet the proposed sweet structure, but these two tetrapeptides were devoid of any sweetness. It may be concluded that the amino and carboxyl groups were improperly located to form hydrogen bonding with the receptor, or that the receptor site had no remaining space to accommodate an additional amino acid residue.

(ii) Modifications at the free $\alpha$-amino group of sweet aspartyl tripeptides (compounds 21-24 in Table I).

Sweet tripeptides L-Asp-D-Ala-L-Ala-OMe ${ }^{7}$ ) and L-Asp-D-Val-L-Val-OMe ${ }^{7)}$ were successfully extended to tetrapeptides 21 and 22 , respectively, but their sweetness potency was significantly decreased. Compound $\mathbf{2 1}$ was sweet when it was tasted as crystals, but not as a
$0.6 \%$ solution. Extension of the latter tripeptide (L-Asp-D-Val-L-Val-OMe) by the addition of a Gly or D-Val residue resulted in tasteless compounds $\mathbf{2 3}$ and $\mathbf{2 4}$, respectively. These results may indicate that these tetrapeptides could scarcely fit into the receptor.

(iii) Modifications at the free $\alpha$-amino group of sweet aminomalonyl dipeptides (compounds $25-28$ in Table I).

An intensely sweet dipeptide (DL-Ama-LPhe-OMe, $300-400 \times$ sucrose $)^{11,12)}$ was extended to tripeptide D-Ala-DL-Ama-L-Phe-OMe (25), with the expectation that compound 25 would be sweet. The extension led to a complete loss of the sweet taste, which is surprising in view of its close structural similarity to the above-mentioned extended aspartyl tripeptide, D-Ala-L-Asp-L-Phe-OMe (11), which was sweet. Then, DL-Ama-L-Phe-OMe was extended by adding the L-antipode (L-Ala) to give 26, which was also devoid of sweetness. Next, a newly synthesized sweet dipeptide, DL-AmaD-Ala-OMe (27), was extended by adding a DAla residue. The resulting tripeptide $(\mathbf{2 8})$ was also bitter. The complete loss of sweetness in 25, 26 and 28 may be related to the AH-B system length; it is known that the distance between the $\mathrm{AH}$ and $\mathrm{B}$ portions was critical. ${ }^{22)}$ The slight change in this distance may have made the peptide inaccessible to the small receptor site.

(iv) Modifications at the free $\beta$-carboxyl group of sweet aspartyl dipeptides (compounds $29-31$ in Table I). 
In an attempt to extend the peptide chain at the $\beta$-carboxyl group of L-Asp-L-Phe-OMe, the original amino and newly introduced carboxyl groups were expected to serve as a proton donor $(\mathrm{AH})$ and proton acceptor (B), respectively, in hydrogen bonding with the receptor. All the peptides (29-31) synthesized here were devoid of any sweetness (Table I).

As already mentioned, some peptides containing an L-Asp residue between the $\mathrm{N}$ - and $\mathrm{C}$-terminal residues were sweet. On the other hand, few sweet L-glutamyl peptides have been reported in the literature, except for L-glutamyl-p-cyanoanilide, ${ }^{28)} \quad \mathrm{CF}_{3} \mathrm{CO}-\mathrm{L}$-glutamyl$p$-cyanoanilide ${ }^{28,29)}$ and $\mathrm{CF}_{3} \mathrm{CO}$-L-glutamyl$p$-nitroanilide, ${ }^{29)}$ which were sweet. In connection with the present study, L-Glu-Gly-OMe and L-Glu-D-Ala-OMe were synthesized, and found to be devoid of sweetness, although they are higher homologues of L-Asp-Gly$\mathrm{OMe}^{3)}$ and L-Asp-D-Ala-OMe, ${ }^{27)}$ which are sweet. To confirm that glutamyl peptides lack any sweet-giving properties, a nonsweet peptide, L-Glu-L-Phe-OMe, was extended at the $\mathrm{N}$-terminus by adding a $\mathrm{D}$-Ala residue; the resulting D-Ala-L-Glu-L-Phe-OMe was found to be bitter, although it is a higher homologue of 11, which is sweet. The lack of sweetness in the glutamic residue-containing peptides may also be related to the AH-B system length, as was mentioned in the case of compounds 25,26 and 28 .

From the results obtained in this study, it can be concluded that the receptor for sweet peptides has a small space left at the site facing the N-terminus of sweet aspartyl dipeptides. This restricted space can accomodate one more small D-amino acid residue. It may also be concluded that there probably exists a spatial barrier at the site facing the $\mathrm{C}$-terminal part of the sweet peptides, because most of the aspartyl dipeptide analogues were intensely sweet, the sweet aspartyl dipeptides decreasing their sweetness potency while elongating their peptide chains toward the C-terminus ${ }^{7,9)}$ and completely losing their sweet taste in the pentapeptides. ${ }^{10)}$ This spatial barrier corresponds to the spatial wall drawn by Iwamura, ${ }^{19)}$ based on a quantitative analysis of the structuretaste relationships in sweet dipeptide analogues.

By increasing the chain length of a sweet peptide, it becomes difficult to fit the small receptor site. The receptor site is so spatially restricted that very subtle changes of structure strongly affect the binding ability to the receptor. A decrease in its binding ability to the receptor reduces or loses the sweetness potency. Thus, only limited peptides such as aspartyl di- and tripeptide analogues, aminomalonyl dipeptide esters, and the abovementioned D-AA-L-Asp-AA-OMe can fit into the receptor and elicit a sweet taste.

Acknowledgment. We thank Mr. K. Iijima for elemental analyses.

\section{References}

1) R. H. Mazur, J. M. Schlatter and A. H. Goldkamp, J. Am. Chem. Soc., 91, 2684 (1969).

2) (a) R. H. Mazur, A. H. Goldkamp, P. A. James and J. M. Schlatter, J. Med. Chem., 13, 1217 (1970); (b) R. H. Mazur, J. A. Reuter, K. A. Swiatek and J. M. Schlatter, J. Med. Chem., 16, 1284 (1973); (c) Y. Ariyoshi, N. Yasuda and T. Yamatani, Bull. Chem. Soc. Jpn., 47, 326 (1974); (d) M. Miyoshi, K. Nunami, H. Sugano and T. Fujii, Bull. Chem. Soc. Jpn., 51, 1433 (1978); (e) M. Kawai, M. Chorev, J. Marin-Rose and M. Goodman, J. Med. Chem., 23, 420 (1980); (f) S. W. King and C. H. Stammer, $J$. Org. Chem., 46, 4780 (1981); (g) T. M. Brennan and M. E. Hendrick, Eur. Pat. Appl. EP 34,876 (Sep. 2, 1981), [C. A., 96, 104780c (1982)]; (h) J. W. Tsang, B. Schmied, R. Nyfeler and M. Goodman, J. Med. Chem., 27, 1663 (1984); (i) W. D. Fuller, M. Goodman and M. S. Verlander, J. Am. Chem. Soc., 107, 5821 (1985); (j) G. P. Rizzi, J. Agric. Food Chem., 33, 19 (1985).

3) Y. Ariyoshi, Agric. Biol. Chem., 40, 983 (1976).

4) M. Fujino, M. Wakimasu, M. Mano, K. Tanaka, N. Nakajima and H. Aoki, Chem. Pharm. Bull., 24, 2112 (1976).

5) C. Mapelli, M. G. Newton, C. E. Ringold and C. H. Stammer, Int. J. Peptide Protein Res., 30, 498 (1987).

6) C. Mapelli, C. H. Stammer, S. Lok, D. F. Mierke and M. Goodman, Int. J. Peptide Protein Res., 32, 484 (1988).

7) Y. Ariyoshi, Bull. Chem. Soc. Jpn., 57, 3197 (1984).

8) M. Rodriguez, J. M. Bland, J. W. Tsang and M. Goodman, J. Med. Chem., 28, 1527 (1985).

9) Y. Ariyoshi, Bull. Chem. Soc. Jpn., 58, 1727 (1985). 
10) Y. Ariyoshi, Bull. Chem. Soc. Jpn., 59, 1027 (1986).

11) M. T. Briggs and J. S. Morley, Brit, Patent, $1,299,265$ (1972).

12) M. Fujino, M. Wakimasu, K. Tanaka, H. Aoki and N. Nakajima, Naturwissenschaften, 60, 351 (1973).

13) M. Lapidus and M. Sweeney, J. Med. Chem., 16, 163 (1973).

14) F. Leli, T. Tancredi, P. A. Temussi and C. Toniolo, J. Am. Chem. Soc., 98, 6669 (1976).

15) M. Goodman, J. Coddington, D. F. Mierke and W. D. Fuller, J. Am. Chem. Soc., 109, 4712 (1987).

16) M. Hatada, J. Jancarik, B. Graves and S.-H. Kim., $J$. Am. Chem. Soc, 107, 4279 (1985).

17) C. H. Görbitz, Acta Chem. Scand., Ser. B 41, 87 (1987).

18) A. van der Heijden, L. B. P. Brussel and H. G. Peer, Chemical Senses and Flavour, 4, 141 (1979).

19) H. Iwamura, J. Med. Chem., 24, 572 (1981).

20) M. Goodman, Biopolymers, 24, 137 (1985).

21) M. W. Thomsen, J. M. Dalton and C. N. Stewart, Chemical Senses, 13, 397 (1988).

22) R. S. Shallenberger, T. E. Acree and C. Y. Lee, Nature, 221, 555 (1969).

23) Partly presented at the 24th Symposium on Peptide
Chemistry, Tokyo, Oct. 1986. Y. Ariyoshi, Y. Hasegawa and N. Nio, Peptide Chemistry 1986, p. 251 (1987); sweet tripeptides extended at the $\mathrm{N}$ terminus of L-Asp-L-Phe-OMe were independently presented at the symposium; T. Takemoto, T. Hijiya and T. Yukawa, Peptide Chemistry 1986, p. 247 (1987).

24) Y. Isowa, M. Ohmori, T. Ichikawa, K. Mori, Y. Nonaka, K. Kihara, K. Oyama, H. Satoh and S Nishimura, Tetrahedron Lett., 1979, 2611.

25) D. A. Laufer and E. R. Blout, J. Am. Chem. Soc., 89, 1246 (1967).

26) G. W. Anderson, J. E. Zimmerman and F. M. Callahan, J. Am. Chem. Soc., 86, 1839 (1964).

27) R. H. Mazur, J. A. Reuter, K. A. Swiatek and J. M. Schlatter, J. Med. Chem., 16, 1284 (1973).

28) M. Kawai, R. Nyfeler, J. M. Berman and $\mathbf{M}$. Goodman, J. Med. Chem., 25, 397 (1982).

29) J. M. Tinti, C. Nofre and D. Durozard, Naturwissenschaften, 68, 143 (1981).

30) C. I. Beck, in "Symposium: Sweeteners," ed. by G. I. Inglett, AVI Publishing Co., Inc., Westport, CT., 1974, pp. 164-181. 